logos_i_ethos_2017_2_(46), s.91-110

DOI: http://dx.doi.org/10.15633/lie.2363

Michał Węcławski

Uniwersytet Wrocławski

\title{
Doświadczenie przed doświadczeniem: wiara jako warunek poznania. Wokół myśli Siemiona L. Franka i Abrahama J. Heschela ${ }^{1}$
}

\section{Uwagi}

O tym, co trudne, mówić jest niełatwo. Tym trudniej, jeśli łatwe się wydaje. Być może, iż temu, kto rozumnie pyta, świat rozumnie odpowiada ${ }^{2}$ lecz pytać rozumnie - to

Michał Węcławski - doktorant w Instytucie Filozofii Uniwersytetu Wrocławskiego. Zainteresowania badawcze: filozofia dialogiczna i religijna, filozofia egzystencji, antropologia filozoficzna. Publikował m.in. w „Studia Philosophica Wratislaviensia” i „Filo-Sofiji”. wyzwanie. Niekiedy też samemu przychodzi dać odpowiedź, i to wówczas trudności jawią się ze szczególną siłą. Jeśli zaś jednym z naczelnych zadań filozofii jest obnażać trudność rzeczy łatwych z pozoru - takich zatem, o których, jak wyznał św. Augustyn, wiemy, czym są, dopóki nikt nas nie pyta - to zagadnienie wiary okazuje się godne filozoficznego zapytywania.

Zadanie, jakie stawiamy sobie w tym szkicu, to próba takiego pytania i takiego odpowiadania, by poprzez zestrojenie rozlicznych znaczeń przybliżyć, na ile to możliwe, czym jest wiara; przybliżyć na drodze rozważań własnych oraz z pomocą myśli cudzych, zwłaszcza - choć nie tylko - Siemiona Franka i Abrahama Heschela. Obie różnią się od siebie, lecz, jak zobaczymy, wspólny jest im pewien ethos lub duch uprawiania filozofii oraz pojmowania człowieka. Wiara nie jest w nich

1 Tekst jest rozbudowaną wersją referatu o tym samym tytule wygłoszonego na organizowanej przez Instytut Filozofii Uniwersytetu Warszawskiego międzynarodowej konferencji Epistemologia doświadczenia religijnego (Warszawa, 26-28 września 2016 roku).

2 Por. G. W. F. Hegel, Wykłady z filozofii dziejów, t. 1, przekł. J. Grabowski, A. Landman, Warszawa 1958, s. 18. 
co prawda punktem centralnym, a jednak okazuje się kategorią niezbędną w procesie zgłębiania sceny ludzkiego doświadczenia, którą zwie się życiem.

Samo hasło: „wiara warunkiem poznania” będzie zaledwie punktem orientacyjnym; okaże się, że ma ona wymiar nie tylko epistemologiczny, czy raczej że - jeśli uważnie się przyjrzeć oraz wsłuchać - nie daje się oddzielić od wymiaru szerszego, który można nazwać egzystencjalnym, a w którym dopiero poznanie prawdziwie się dokonuje. W perspektywie tej wypadnie zasygnalizować takie sprawy, jak rozum, tajemnicę, ciemność i światło, słyszenie i widzenie, przeszłość i przyszłość, dialogiczny wymiar wiary i w końcu jej spodziewane owoce.

\section{Wobec rozumu}

By uchwycić związek wiary i poznania, przechodząc do porządku nad tkwiącą tu na pozór sprzecznością, należałoby pochylić się nad niełatwym zagadnieniem stosunku wiary do rozumu. Tutaj wszakże dość będzie wskazać, że rozum może przeczyć wierze lub nie, zależnie od tego, jak będzie rozumiany.

To do drugiego ze wskazanych znaczeń odwołuje się Frank, kiedy powiada, że

„serce” nie jest, jak to się zwykło myśleć, jakąś szczególną instancją przeciwstawną „rozumowi”; ono jest właśnie centrum całościowego, wszechobejmującego bytu wewnętrznego, którego jednym z promieni może być także „rozum”. [...] może on towarzyszyć żywemu uchwyceniu Bóstwa, współuczestniczyć w nim i tym samym nadawać [temu aktowi] jeszcze większą jasność ${ }^{3}$.

Podobne stanowisko zajmuje Heschel, dzięki czemu stwierdzić może wzajemną zależność wiary i rozumu:

3 S. L. Frank, Niepojęte. Ontologiczny wstęp do filozofii religii, przekł. T. Obolevitch, Tarnów 2007, s. 224. 
Bez rozumu - czytamy - wiara staje się ślepa; bez niego nie potrafilibyśmy odnieść naszych wejrzeń religijnych do konkretnych kwestii życiowych. Kult rozumu jest arogancją i zdradza brak inteligencji. Ale odrzucenie rozumu jest tchórzostwem i świadczy o braku wiary ${ }^{4}$.

Zarówno rozum, jak i wiara nie są ani wszechogarniające, ani samowystarczalne. [...] Rozum to konieczny czynnik wiary, nadający formę temu, co często staje się gwałtowne, ślepe i wyolbrzymione przez wyobraźnię. Wiara bez rozumu jest niema, rozum bez wiary jest głuchy ${ }^{5}$.

O niesprzeczności wiary i poznania przekonywali obok Franka inni myśliciele rosyjscy. Jeśli wiara - jak pisał Mikołaj Bierdiajew - jest „wewnętrznym doświadczeniem duchowym” i „odrodzeniem duszy”, musi się okazać nie tyle pomocna, ile niezbędna myśleniu, będąc „wewnętrznym oświeceniem aktu poznawczego"6. Całej zresztą tradycji wschodniej właściwe jest owo przekonanie, że

wiara to przeddyskursywne, intuicyjne poznanie rzeczywistości boskiej. Ośrodkiem takiego poznania nie jest rozum, lecz umysł ([nous]), utożsamiany z „sercem”, czyli organem wewnętrznej, duchowej integracji osoby. [...] Poznanie przez wiarę - kardiognoza - nie poprzestaje na konstatacji poznawanego Przedmiotu, ale ma prowadzić do całkowitej przemiany ([metanoia]) myślenia i życia ${ }^{7}$.

Rozumienie to, nieobce zarówno dla Franka, jak i dla Heschela, pozwala uniknąć upraszczającego radykalizmu domniemanej przeciwstawności,

4 A. J. Heschel, Bóg szukajacy człowieka. Podstawy filozofii judaizmu, przekł. A. Gorzkowski, Kraków 2015, s. 29.

5 A. J. Heschel, Człowiek nie jest sam. Filozofia religii, tłum. K. Wojtkowska, Kraków 2008, s. 146.

${ }_{6}$ M. Bierdiajew, Rozważania o egzystencji. Filozofia samotności i wspólnoty, tłum. H. Paprocki, Kęty 2002, s. 12.

7 T. Obolevitch, Wiara jako „locus philosophicus” myśli rosyjskiej, w: Rosyjska metafizyka religij$n a$, red. T. Obolevitch, W. Kowalski, Tarnów 2009, s. 47. Na temat związku wiary i poznania w myśli rosyjskiej zob. też P. Evdokimov, Poznanie Boga w Kościele wschodnim, przeł. A. Liduchowska, Kraków 1996, s. 15-16, a także J. Krasicki, Człowiek i Bóg w tradycji rosyjskiej, Kraków 2012, passim, zwłaszcza s. 141-143. 
a poznaniu, wierze oraz doświadczeniu przywrócić pierwotną i zgoła naturalną więź.

\section{Wiara jako warunek}

Wspomniane uniknięcie oraz przywrócenie może się dokonać przy odpowiednim pojmowaniu filozofii jako opartej, jak postulował Frank, na „żywym doświadczeniu religijnym”, i odpowiednim pojmowaniu religii jako osobistej i zanurzonej w życiu podstawy rozumienia świata. Wiara może się wówczas jawić kategorią epistemologiczną, i to kategorią przydatną nie tylko w sferze związanej bezpośrednio z religią; zarazem sama religia i doświadczenie religijne muszą oznaczać więcej niż zespół dogmatów i zorganizowany kult, będąc raczej właściwym człowiekowi sposobem istnienia nastawionym na pełne uczestnictwo w rzeczywistości ${ }^{9}$.

Jeśli zatem wiara jest warunkiem poznania, oznacza to, że bez niej nie dociera się do tego, co autentycznie będące, a poznanie jest niepełne. Nie chodzi przy tym jedynie - jak chcieli niektórzy rosyjscy myśliciele ${ }^{10}-$ o wiarę jako pewność istnienia przedmiotu poznania, co byłoby zapewne zbyt trywialne, lecz o egzystencjalnie uwarunkowane przylgnięcie całym sobą do intuicji, że przed wszelkim pojmowaniem jesteśmy zanurzeni w coś, co nieskończenie nas przekracza, a co stanowi źródło sensu i siły naszego bycia. „Wiara - pisze Bernhard Welte - że we wszystkim

8 S. L. Frank, Dowód ontologiczny i inne pisma o wiedzy i wierze, przekł. T. Obolevitch, Kraków 2007, s. 20. Por. M. Bierdiajew, Rozważania o egzystencji..., dz. cyt., s. 14. Innymi słowy, chodziłoby o to, co Franz Rosenzweig nazwał „filozofią doświadczającą” (Nowe myślenie, w: F. Rosenzweig, Gwiazda Zbawienia, przeł. T. Gadacz, Warszawa 2012, s. 666).

9 „Należy mówić nie o «religijnym doświadczeniu» obok doświadczeń codziennych, lecz o religijnym wymiarze naszego doświadczenia (naszych doświadczeń). Jak łatwo dostrzec, nie jest ono teraz izolowane od innych doświadczeń i nie jest też czymś wyjątkowym i niekiedy tylko się przydarzającym człowiekowi. Nie wymaga też przygotowania człowieka do jego przyjęcia. Odwrotnie, jest ono teraz związane z istnieniem człowieka, dla którego «istnieć» zawsze oznacza nie ograniczać się do «tu i teraz», lecz wykraczać poza, bytować metafizycznie. Doświadczenie religijne jest wyrazem takiego bytowania” (M. Szulakiewicz, Religia i czas, Toruń 2008, s. 137; zob. też s. 152).

10 Por. np. T. Obolevitch, Wiara jako „locus philosophicus” myśli rosyjskiej, dz. cyt., s. 51. 
i ponad wszystkim, co przeżywamy pod różnymi postaciami w naszym ziemskim, relatywnym istnieniu, zawiera się rzeczywisty, nieprzemijalny i konieczny sens, jest wcześniejsza od wszelkiego poznania""11 Heschel stwierdzi zaś: „Wiara raczej poprzedza każde dotykalne doświadczenie, niż wypływa z niego. Bez posiadania wiary żadne doświadczenie nie jest w stanie przekazać nam religijnego znaczenia" ${ }^{\prime 2}$.

Poznanie owej sfery pierwotnego sensu przekracza ograniczenia języka i wymyka się konceptualizacji. Realność (w rozumieniu Franka), w przeciwieństwie do tego, co rzeczywiste, nie daje ująć się w słowa ani zamknąć w granicach pojęćc ${ }^{13}$. Cały świat i całe nasze życie - Frank i Heschel przekonują o tym pospołu - zanurzone są w głębi nieusuwalnej tajemnicy ${ }^{14}$. Wszelako, wedle Franka - wiernego ucznia Mikołaja z Kuzy - to, co niepojęte, nie jest niepojmowalne i daje się pojąć przez niepojmowalnośćc ${ }^{15}$. Takoż dla Heschela, jakkolwiek posługuje się innymi terminami, najwyższa rzeczywistość, dostępna wierze, stanowi dziedzinę tego, co niewysłowione.

Najgłębsze wejrzenie wyłania się z chwil niewysłowionego poruszenia, chwil zadziwienia, bojaźni, uwielbienia, strachu, drżenia i absolutnego zdumienia; ze świadomości majestatu, ze spostrzeżeń, które możemy uchwycić, lecz których nie potrafimy wyrazić, z odkrycia tego, co nieznane; [...] najgłębsze wejrzenie wyłania się $\mathrm{z}$ wiedzy poprzez niewiedze (knowledge by inacquaintance). U szczytu takich chwil osiągamy pewność, że życie ma sens, że czas to coś więcej niż przemijanie, że poza całym stworzeniem jest ktoś, kto się o nie troszczy ${ }^{16}$.

11 B. Welte, Czym jest wiara? Rozważania o filozofii religii, przeł. W. Patyna, Warszawa 2000, s. 31 .

12 A. J. Heschel, Człowiek nie jest sam..., dz. cyt., s. 81; zob. też s. 27.

13 Zob. S. L. Frank, Niepojęte..., dz. cyt., s. 54.

${ }_{14} \mathrm{Na}$ temat tajemnicy zob. np. A. J. Heschel, Bóg szukający człowieka..., dz. cyt., s. 75-76; A. J. Heschel, Człowiek nie jest sam..., dz. cyt., s. 58-59.; S. L. Frank, Niepojęte..., dz. cyt., s. 42, 55, 94, 203; S. L. Frank, Dowód ontologiczny..., dz. cyt., s. 200-201. Zob. też L. Augustyn, Myślenie z wnętrza objawienia. Studium filozofii Siemiona L. Franka, Kraków 2003, s. 102-111.

15 Zob. S. L. Frank, Niepojęte..., dz. cyt., s. 248; S. L. Frank, Dowód ontologiczny ..., dz. cyt., s. 53.

16 A. J. Heschel, Bóg szukający człowieka..., dz. cyt., s. 166. Heschel podkreśla, że źródłem wiary jest bojaźń. Zob. A. J. Heschel, Kim jest człowiek?, przeł. K. Wojtkowska, Łódź 2014, s. 152, 194; 
Według Franka całość bytu dana jest przed jego pojęciem ${ }^{17}$, u Heschela świadomość nieznanego poprzedza świadomość tego, co znane ${ }^{18}$, a każde poznanie suponuje „wiedzę przedpojęciową" ${ }^{19}$. Istnieje przeto pierwotne tło wszelkiego poznania i doświadczenia, doświadczane i poznawane dzięki wierze. Kontakt z tą sferą Frank nazwie doświadczeniem religijnym „doświadczeniem takiej realności, którą rozumiemy jako warunek wszelkiego doświadczenia i wszelkiej myśli - jako wspólne tło, oparcie, glebę, ostatecznie ukoronowanie wszystkiego, co nam dane i czym żyjemy"20.

Pewność wiary, związana z tym doświadczeniem, zakorzenia człowieka w absolucie. Jako „samopoznanie pogłębione aż do ujrzenia ostatniej głębi i absolutnej podstawy naszego życia duchowego"21, wiara polega na przylgnięciu całym sobą do objawionej przed oczami umysłu prawdy, a ostatecznie do „samoukazania się Boga w człowieku”22. W tym wymiarze jest ona dla Franka „specyficzną wiarygodnością [...] bezpośrednio dostrzeganą $\mathrm{w}$ doświadczeniu o szczególnym, duchowym charakterze"23, w której - jako w „żywym pałaniu ducha” - niepodobna się mylićc ${ }^{24}$. Wyraża się zarazem - na poziomie ontologicznym - w przekonaniu o zasadniczym „metafizycznym monizmie bytu”, genetycznej jedności świata zewnętrznego i wewnętrznego, zmysłowego i duchowego ${ }^{25}$.

także A. J. Heschel, Bóg szukający człowieka..., dz. cyt., s. 100, 194, A. J. Heschel, Człowiek nie jest sam..., dz. cyt., s. 78 .

17 Zob. S. L. Frank, Niepojęte..., dz. cyt., s. 38; także S. L. Frank, Pierwsze określenie i istota intuicji, przeł. B. Czardybon, „Logos i Ethos” 25 (2008) nr 2, s. 183.

18 Zob. A. J. Heschel, Człowiek szukający Boga. Szkice o modlitwie i symbolach, tłum. V. Reder, Kraków 2008, s. 184.

19 A. J. Heschel, Bóg szukający człowieka..., dz. cyt., s. 149.

20 S. L. Frank, S nami Bog. Tri razmyszlenija, Paris 1964, s. 57, za: L. Augustyn, Myślenie z wnętrza objawienia..., dz. cyt., s. 148. Jak wyrazi się L. Augustyn, u Franka „w doświadczeniu religijnym mamy sytuację intymnej bliskości tego, co oddalone: na jego gruncie immanencja i Transcendencja spotykają się" (s. 148-149).

${ }_{21}$ S. L. Frank, S nami Bog..., dz. cyt., s. 67-68, za: L. Augustyn, Myślenie z wnętrza objawienia..., dz. cyt., s. 149. Na temat wiary jako intuicji zob. też T. Obolevitch, Problematyczny konkordyzm. Wiara i wiedza w myśli Włodzimierza S. Sołowjowa i Siemiona L. Franka, Tarnów 2006, s. 146nn.

22 S. L. Frank, Dowód ontologiczny..., dz. cyt., s. 154.

${ }^{23}$ S. L. Frank, Dowód ontologiczny..., dz. cyt., s. 150; zob. też s. 8-9.

24 S. L. Frank, Dowód ontologiczny..., dz. cyt., s. 153-154.

25 Zob. S. L. Frank, Niepojęte..., dz. cyt., s. 211. 
Wydaje się przeto, że w owym bezpośrednim widzeniu wiara znosi nie tylko tajemnicę, lecz i samą wiarę - rozumianą wszak powszechnie jako „przekonanie o tym, czego nie widzimy” $(\mathrm{Hbr} 11,1)^{26}$.

\section{Wiara widząca, wiara słysząca}

Tajemnicę, jako to, co zakryte i zakrywające, na co dzień spowija mrok, a wszystko, co daje się w niej dostrzec, to zaledwie kontury i cienie, jawiące się niewyraźnie niby poprzez mgłę. Zdaniem Heschela „wszystko to, co widoczne, nie dotyka sfery najwyższej. To, co najwyższe, pozostaje ukryte”, lecz wiara w Boga, „wiążąc się z dziedziną najwyższą, z królestwem tajemnicy"27, jest w stanie dosięgnąć tej sfery. Ciemność wiary, Abrahamowe doświadczenie niewidzenia celu, do którego się zmierza, stanowi fundament, na którym wznosi się jej związek z tajemnicą. Owo doświadczenie przed doświadczeniem otwiera na Niewysłowione albo Niepojęte, przybliża tajemnicę i pozwala usłyszeć jej wymowne milczenie.

U Franka - choć dużo częściej niż Heschel pisze o wzroku - tylko pozornie brak tego akcentu, albowiem bezpośrednie ujrzenie absolutu w jego pełni dokonuje się wyłącznie przez niewiedzę, wymaga przeto początkowej rezygnacji z widzenia na rzecz „całkowitej” i „dziecięcej” niewinności ${ }^{28}$. Dla niego wiara jest najpierw „stanem ducha określonym poczuciem naszej nierozerwalnej więzi z pokrewnym nam boskim

26 Zob. np. Tomasz z Akwinu, Suma teologiczna, t. 24: Wcielenie Słowa Bożego, tłum. St. Piotrowicz, Londyn 1962, s. 69 (III, q. 7, a. 3): „Wiara w ścisłym znaczeniu polega na wierzeniu w rzeczy niewidziane. Powiedzenie natomiast, że wierzymy w coś, co oglądamy, jest nieścisłe. Dotyczy ono przeżyć podobnych do wiary pod względem pewności lub mocy przekonania”. Autor sugeruje na tej podstawie, że Chrystus, mając „pełne widzenie Boga w jego istocie”, nie mógł posiadać wiary (tamże).

27 A. J. Heschel, Bóg szukający człowieka..., dz. cyt., s. 150. Wrażliwość na tajemnicę i „duchowe zamieszkanie" w niej stanowią dla Heschela warunek wstępny wiary. Zob. A. J. Heschel, Bóg szukajacy człowieka..., dz. cyt., s. 194; A. J. Heschel, Człowiek nie jest sam..., dz. cyt., s. 82. W innym miejscu przytacza też słowa Rabiego Loewa z Pragi: „Wiara, zaufanie Bogu, to przywiązanie do sfery najwyższej, do sfery tajemnicy. Oto istota wiary. Wiarą jesteśmy zdolni sięgnąć sfery misterium. Może dlatego właśnie słowo oznaczające wiarę (amen, amanah, emunah) zaczyna się na pierwszą literę alfabetu - sięga samego początku wszelkich istot [Netivoth Olam, netiv haavodah, rozdz. 2]" (A. J. Heschel, Człowiek szukający Boga..., dz. cyt., s. 104).

28 Zob. S. L. Frank, Niepojęte..., dz. cyt., s. 243. 
żywiołem nieskończonej miłości, z niewyczerpanym skarbem dobra, pokoju, łaski, świętości; i tylko poprzez ten żywioł i w nierozerwalnej więzi z nim możemy przejrzeć, poczuć jego najgłębsze praźródło - Boga żywego" ${ }^{29}$. Dopiero wtedy przed oczyma duszy może się dokonać objawienie samooczywistości, kiedy to „w intuicyjnej, metalogicznej wiedzy ujmujemy niepojęte w sobie - niejako jawną, jasno oświetloną, widzialną tajemnicę, która nie przestaje być tajemnicą przez to, że otwarcie ukazuje się nam $\mathrm{i}$ jest przez nas kontemplowana" ${ }^{30}$.

Choć zatem wiara rodzi się w ciemności, uzupełniana jest przez światło i udzielając duchowego wzroku - a może sama nim będąc - pośredniczy w widzeniu, by doprowadzić wreszcie do stanu, w którym ogląda się prawdę „twarzą w twarz”. Dopóki jest w drodze, polega na słuchu, lecz im bliżej końca - znakomicie w Gwieździe Zbawienia pokazał to Franz Rosenzweig $^{31}$ - tym bardziej dopełniana jest przez patrzenie ${ }^{32}$.

Nigdy wszakże, dopóki jest wiarą, $\mathrm{w}$ drodze być nie przestanie, a przeto zdana jest, jak ujął to Tomasz z Akwinu, na nieustanny „niepokój myśli”33. „Nie wie ona - twierdzi Karol Tarnowski - gdzie się znajduje, wie tylko, że nie może spocząc" ${ }^{34}$. Jakkolwiek bowiem jest pewnością, nie daje się odłączyć od ryzyka, skoro świat, w jakim przyszło jej się znaleźć, naznaczony jest

29 S nami Bog. Tri razmyszlenija, Paris 1964, s. 92, za: L. Augustyn, Myślenie z wnętrza objawienia..., dz. cyt., s. 151.

30 S. L. Frank, Niepojęte..., dz. cyt., s. 54; zob. też s. 235-236.

31 Zob. F. Rosenzweig, Gwiazda Zbawienia, dz. cyt., s. 657-658 i in. Podejmuję ten temat w tekście Franz Rosenzweig - filozof hebrajski. O dawnych korzeniach nowego myślenia, w: Bóg - człowiek - świat. Szkice z myśli filozoficznej Franza Rosenzweiga, red. D. Jacyk, Wrocław 2017, s. 49-80, zwłaszcza s. 62-64 (o prymacie słuchu) i 74-75 (o przejściu do widzenia).

32 „W dziejach człowieka zbawionego przez wiarę dokonuje się przejście od otwartej i niejasnej sytuacji słuchacza, do którego ma dotrzeć słowo [...], do ostatecznie jasnej sytuacji człowieka zbawionego, który widzi” (T. Węcławski, Wiara ze słuchania i widzenie, „Znak” 473 [1994] nr 10, s. 77).

${ }_{33}$ De veritate 14,1 ad 5, zob. J. Pieper, O miłości, nadziei i wierze, przeł. I. Gano i K. Michalski, Poznań 2000, s. 227. Zawarte w wierze bojaźń i drżenie z właściwym sobie przejęciem podkreślał Lew Szestow: „Wiara [...] jest bojaźnią, oczekiwaniem, tęsknotą, trwogą, nadzieją, nieustannym przeczuwaniem wielkiej niezwykłości, troską i nieukontentowaniem tym, co doczesne, oraz niemożnością przeniknięcia tego, co przyszłe" (L. Szestow, Sola fide. Tylko przez wiarę, przeł. C. Wodziński, Warszawa 1995, s. 270).

34 K. Tarnowski, Usłyszeć niewidzialne. Zarys filozofii wiary, Kraków 2005, s. 270. 
nieusuwalnym wątpieniem. Ten właśnie kontekst, $\mathrm{w}$ jaki zawsze już z góry jest wpisana, fakt, że „zakłada zawsze więcej niż może [...] pochwycić” ${ }^{35}$ i że przyjmuje za będące coś, co nieobecne (Augustynowe creduntur absentia), uprzytomnia, że może się ona pomylić. Ryzyko wiary jest wszelako znamieniem jej szlachetności, albowiem „wieże są bardziej podatne na wstrząsy niż groby" ${ }^{36}$. Komu wszelka wiara jest obojętna, kto nie jest zdolny podjąć ryzyka i wierzyć, niechby nawet przez zaprzeczenie - ten z dala od niebezpieczeństw składa do grobu swoje człowieczeństwo ${ }^{37}$.

\section{5. Życie}

Bez wiary bowiem nie tylko nie ma ostatecznego, głębokiego poznania, ale nie ma zgoła życia. Prawdziwe życie jest nieobecne ${ }^{38}-\mathrm{i}$ być może dopiero wiara zbliża do jego uobecnienia. Jak pisze Lew Tołstoj:

Gdzie życie, tam wiara, odkąd ludzkość istnieje, daje możność życia, a główne rysy wiary są wszędzie i zawsze te same. Jakiekolwiek i komukolwiek daje odpowiedzi, jakąkolwiek byłaby wiara, każda jej odpowiedź nadaje ograniczonemu istnieniu człowieka wymiar nieskończoności - nieunicestwiany przez cierpienie i śmierć. [...] Wiara jest poznaniem sensu ludzkiego życia, wskutek czego człowiek nie unicestwia swego istnienia, lecz żyje. Wiara jest siłą życia. [...] Bez wiary nie można żyćc $c^{39}$.

Tak tedy warunek poznania okazuje się warunkiem życia, albowiem prawdziwe poznanie nie sprowadza się tylko do wyizolowanego ruchu

35 K. Tarnowski, Usłyszeć niewidzialne..., dz. cyt., s. 83.

36 A. J. Heschel, Człowiek nie jest sam..., dz. cyt., s. 82.

37 Niech zilustrują to słowa Filka: „Niezdolność do wierzenia w podstawowe przedmioty wiary czy do wierzenia w ich zaprzeczenia oznacza niezdolność do samookreślenia się i ma za swą konsekwencję nieokreśloność, bezkształtność człowieka. Człowiek taki nie jest osobiście obecny. Jest jedynie bezwładnym materiałem poddanym zręczności zewnętrznych «kształcicieli»" (Etyka jako wiara $w$ dobro, w: J. Filek, Filozofia jako etyka, Kraków 2001, s. 260).

38 Por. A. Rimbaud, Sezon w piekle, w: A. Rimbaud, Wiersze. Sezon w piekle. Iluminacje. Listy. tłum. A. Międzyrzecki, Kraków 1993, s. 173; E. Lévinas, Całość i nieskończoność. Esej o zewnętrzności, przeł. M. Kowalska, Warszawa 2002, s. 18.

39 L. Tołstoj, Spowiedź, przekł. B. Baran, Warszawa 2011, s. 120-121. 
rozumu, lecz jest - jak wiara - integralnym aktem całej osoby ${ }^{40}$ zanurzonej i uczestniczącej w tajemnicy bytu. Myślenie, poznanie nie daje się więc oddzielić od bytu, ponieważ samo zeń wyrasta i wchodzi w jego skład ${ }^{41}$.

Wiara nie jest zatem formą jeszcze-nie-wiedzy ${ }^{42}$, przyświadczeniem, sądem ani nawet aktem - lecz fundamentalną postawą wobec tego, co nam się przytrafia, wobec świata i tego, co świat przekracza, sposobem bycia polegającym na intencjonalnym otwarciu egzystencji w najgłębszym jej pokładzie, który nie bez racji nazywano sercem.

Nieprzerażona powszechnym ograniczeniem umysłu - czytamy u Heschela utrzymuje się jako postawa wobec całej rzeczywistości: uważać małe rzeczy za wielkie, traktować błahe sytuacje poważnie, rozważać codzienne sprawy w odniesieniu do tego, co wieczne ${ }^{43}$.

Jako taka jest warunkiem poznania, ale i sama jest uwarunkowana; stanowi początek, lecz nie absolutny: jako odpowiedź, wynurzając się z płynącego z głębi bytu pytania, zakorzenia się w czymś, co ów początek umożliwia. Jako punkt wyjścia nie tylko rozpoczyna proces poznania, ale leży u podstaw samej egzystencji. „Bez niej - powiada Bernhard Welte - w ogóle nic nie może się rozwijać. Na początku nie ma ani czynu,

${ }^{40} \mathrm{O}$ integralnym i integrującym charakterze wiary zob. np.: A. J. Heschel, Bóg szukający człowieka..., dz. cyt., s. 195 (wiara - „akt całej osoby, umysłu, woli, serca”); P. Tillich, Dynamika wiary, tłum. A. Szostkiewicz, Poznań 1987, s. 33 (wiara - „angażuje całość osobowości”); B. Welte, Czas i tajemnica, przeł. K. Święcicka, Warszawa 2000, s. 165 (wiara - „całościowe bycie sobą"); K. Tarnowski, Ustyszeć niewidzialne..., dz. cyt., s. 259 (wiara - „jednoczy w sobie różne strumienie naszej egzystencji”); G. Marcel, Tajemnica bytu, tłum. M. Frankiewicz, Kraków 1995, s. 382 (akt wiary - „akt osoby rozpatrywanej jako rzeczywista jedność”); L. Dupré, Inny wymiar. Filozofia religii, przekł. S. Lewandowska-Głuszyńska, Kraków 2003, s. 27 (wiara - „wszystko integrujący czynnik życia”).

${ }_{41}$ Por. np. M. Bierdiajew, Rozważania o egzystencji..., dz. cyt., s. 35 i in.

${ }^{42}$ Jak choćby u Klemensa z Aleksandrii, gdzie „wiara - pisze Dariusz Karłowicz - jest rodzajem częściowo tylko uzasadnionej prawdziwej hipotezy, której potwierdzenie uzyskujemy u kresu moralnej i poznawczej przemiany, kiedy to w swym najwyższym punkcie gnoza przekształca się w miłość" (D. Karłowicz, Sokrates i inni święci. O postawie starożytnych chrześcijan wobec rozumu i filozofi, Warszawa 2005, s. 126). Zob. też K. Jaspers, Wiara filozoficzna wobec objawienia, przeł. G. Sowinski, Kraków 1999, s. 56.

43 A. J. Heschel, Człowiek nie jest sam..., dz. cyt., s. 78. 
ani wiedzy. Na początku jest wiara" ${ }^{44}$. Tak rozumianej wierze przeciwstawia się nie rozum, lecz bezsens i obezwładniające poczucie absurdu. Jest, powiada Welte, wielkim „Tak” wypowiedzianym wobec istnienia ${ }^{45}$, czy też, jak u Rosenzweiga, zachodzącą przed wszelkim doświadczeniem afirmacją nie-nicości ${ }^{46}$.

Afirmacja ta, przychodząc „ze słuchania”, jest czymś, co w człowieku się wydarza, wypływa z wnętrza jego samego, ale zarazem jakoby z odległego, ukrytego w otchłani wieczności źródła. Oto paradoks: wiara wiąże się z wolnością, jednak człowiek nie wybiera wiary - to ona wybiera człowieka ${ }^{47}$ i dlatego niepodobna jej posiadać, można w niej jedynie byćc ${ }^{48}$.

\section{Wobec czasu}

Skoro tedy wiara jest „uczestniczeniem pełnią swego bytu w przedmiocie naszej ostatecznej troski” ${ }^{49}$ i „egzystencjalnym stosunkiem do samej

${ }^{44}$ B. Welte, Czym jest wiara?..., dz. cyt., s. 26. Na s. 32 czytamy: „Nasze działanie zawsze niewidocznie wyrasta $\mathrm{z}$ wiary w rzeczywisty sens i rzeczywistą trwałość gruntu, po którym stąpamy. [...] Wiara [...] jest wcześniejsza od wszelkiego poznania. Jako taką wiarę można określić wiarę w Boga. [...] Umożliwia [ona] wszelkie formy dokonywania przez nas istnienia”. Zob. też uwagi Tarnowskiego (Usłyszeć niewidzialne..., dz. cyt., s. 440-442) na temat „wiary fundamentalnej” otwarcia się na dobro i „pra-zaufania” wobec życia.

45 „Wiara oznacza zatem afirmatywne «Tak», które jest tak silne, że obejmuje sobą i koniec końców przezwycięża negujące «Nie», które się w nim z konieczności zawiera. Dopiero dzięki wierze możemy również w ciemnym świecie żyć - i umrzeć - z pokornym i w końcu zwycięskim «Tak» na ustach" (B. Welte, Filozofia religii, tłum. G. Sowinski, Kraków 1996, s. 179, 184). Zob. B. Welte, Czas i tajemnica, dz. cyt., s. 167-168; B. Welte, Czym jest wiara?..., dz. cyt., s. 26, 31-32.

${ }^{46} \mathrm{O}$ wierze u Rosenzweiga jako afirmacji nie-nicości oraz doświadczeniu pewności istnienia „człowieka, świata, Boga” zob. T. Gadacz, Bóg w filozofii Franza Rosenzweiga, w: T. Gadacz, Filozofia Boga w XX wieku. Od Lavelle’a do Tischnera, Kraków 2007, s. 99-100.

47 Znamienne są słowa Marcela: „Im bardziej dusza zbliża się do wiary i zdaje sobie sprawę $\mathrm{z}$ transcendencji jej przedmiotu, tym bardziej przekonuje się, że jest zupełnie niezdolna do wytwarzania wiary, do wydobywania jej z własnej głębi” (G. Marcel, Rozważania na temat wiary, w: G. Marcel, Być i mieć, przeł. D. Eska, Warszawa 2001, s. 304-305). Podobnie K. Tarnowski, Usłyszeć niewidzialne..., dz. cyt., s. 267. Zob. także L. Szestow, Sola fide..., dz. cyt., s. 262.

48 Por. G. Marcel, Tajemnica bytu, dz. cyt., s. 349. W innym miejscu: „Wiara nie odnosi się tylko do bytu - [...] ona należy do bytu, jest moim bytem, naprawdę jest ona podstawą tego, czym jestem" (G. Marcel, Od sprzeciwu do wezwania, przeł. S. Ławicki, Warszawa 1965, s. 221).

49 P. Tillich, Dynamika wiary, dz. cyt., s. 54. 
rzeczywistości w jej konkretności”50, nie sposób założyć, że jedynym punktem odniesienia jest dla niej wieczność; jeśli słusznie wiążemy ją z tym, co prawdziwie ludzkie, należy raczej przyjąć, że aby zaistniała i aby można dokonywać jej opisu, niezbędny jest czas i związane z nim pojęcia ${ }^{51}$.

Jako „pewność tego, czego się spodziewamy” (Hbr 11, 1), wybiega w przyszłość, i jest w tej mierze - utwierdzona w nieobecności tego, co nadejdzie - synonimem nadziei. Jeśli wiara wiąże się z mrokiem, nadzieja przynosi światło, rozjaśniając niepewność tego, co nieznane; oczy wiary, zrazu zaciemnione, niecierpliwie wypatrują jutra, które przyniesie ziszczenie obietnicy. „Wierzy się jedynie w przyszłość - pisze Miguel de Unamuno. - Wierzyć w to, czegośmy nie widzieli, znaczy wierzyć w to, co zobaczymy. Powtarzam więc, że wiara jest wiarą w nadzieję; wierzymy w to, na co mamy nadzieję, czego oczekujemy" ${ }^{52}$. Dzięki temu wiara, jako siła nadziei, pomaga stawić czoła przeciwnościom i budować wytrwałość, w pewności istnienia innego, trwalszego porządku otwierając się na spodziewane dobro ${ }^{53}$. Owo otwarcie nie dokonuje się wszakże w jednym wyłącznie kierunku.

Choć bowiem prima facie to przyszłość definiuje wiarę, nie należy zapoznawać faktu, że nie gorzej daje się ona określić także przez związek z tym, co było; ufnie wychylona w stronę „jeszcze nie”, zakorzenia się zarazem w pewnym ,już. Zwłaszcza w refleksji żydowskiej przeszłość jest źródłem, z którego wiara czerpie swoją siłę. Jak powie Heschel, „wiara to pamięć, a nie tylko uznanie za prawdę zbioru dogmatów” ${ }^{54}$; „pamięć jest źródłem wiary. Posiadać wiarę to wspominać" 55 . Wspominać wszelako nie zbiór dogmatów, lecz przynoszące wolność i siłę wejrzenie, doświad-

${ }^{50}$ K. Tarnowski, Ustyszeć niewidzialne..., dz. cyt., s. 259.

51 Szerzej o roli czasu w refleksji nad religią i człowiekiem w ogóle zob. zwłaszcza M. Szulakiewicz, Religia i czas, dz. cyt., s. 36-41 i in. Zob. też E. Wolicka, Wiara i czas. Przyczynek do chrześcijańskiej hermeneutyki dialogu, „Znak” 407 (1989) nr 4, s. 34nn.

${ }_{52}$ M. de Unamuno, Wiara, nadzieja, miłość, w: M. de Unamuno, O poczuciu tragiczności życia wśród ludzi i wśród narodów, przeł. H. Woźniakowski, Kraków-Wrocław 1984, s. 219. Zob. też K. Mech, Logos wiary. Między boskością a racjonalnością, Kraków 2008, s. 34-35.

53 Por. K. Tarnowski, Ustyszeć niewidzialne..., dz. cyt., s. 237.

54 A. J. Heschel, Bóg szukający człowieka..., dz. cyt., s. 267.

55 A. J. Heschel, Człowiek nie jest sam..., dz. cyt., s. 137. 
czenie nieusuwalnej pewności - jeśli nie od razu własne, to co najmniej, wskutek zawierzenia, przyswojone ${ }^{56}$. Pamięć, nadająca wierze tożsamość, to nie uporczywe spoglądanie za siebie, ale żywa świadomość, że krocząc naprzód, to nie my jesteśmy tymi, którzy przecierają szlaki. Ostatecznie tedy to, co było, i to, co nadejdzie, zbiega się, a poprzez wierność - syntezę przeszłości i przyszłości - wiara ukazuje swój głęboko osobowy i dialogiczny wymiar ${ }^{57}$.

\section{Zawierzenie}

Ilekroć bowiem wierzę w coś - wierzę komuś, a wierzyć komuś oznacza ufać, że nie zawiodą pokładane w nim nadzieje. Jak wyrazi to Unamuno:

Wiara zakłada element osobowy, obiektywny. Nie tyle w coś wierzymy, co wierzymy komuś, kto nam obiecuje czy zapewnia nas o tym lub owym. [...] Ufa się jedynie osobom. [...] I tak samo wierzy się temu - i w tego - kto mówi nam prawdę i daje nadzieję, a nie bezpośrednio, wprost w samą prawdę, nie w samą nadzieję ${ }^{58}$.

Odniesiona do zaufania, bardziej niż słyszenie bądź widzenie daje się pojąć jako przeżywanie obecności, które można porównać do odczuwania ciepła kogoś, kto jest w pobliżu. Być zaś w pobliżu to pokornie uznać czyjąś odrębność, nieusuwalną nawet w sytuacji najintymniejszej łączności. Wiara, nawet jeśli istotnie zarówno słyszy, jak i widzi, nie celuje ani w jednym, ani w drugim, lecz pragnie nade wszystko oddać się w ręce, które rozpoznaje jako godne powierzenia się im bez reszty. Wskutek tej szlachetnej uległości, będącej „pozytywną zgodą na poleganie nie na sobie” ${ }^{59}$, uczestnicząc

56 Zob. A. J. Heschel, Bóg szukający człowieka..., dz. cyt., s. 167.

57 Jak trafnie napisze Tomáš Halík, wiara to „siła, energia, która przetwarza życie z monologu w dialog" (Różnorodność pojednania, za: T. Halík, Żyć z tajemnicą. Impulsy do rozmyślań nad wiarą, przekł. A. Babuchowski i J. Zychowicz, Kielce 2015, s. 14).

58 M. de Unamuno, Wiara, nadzieja, miłość, dz. cyt., s. 206-207. „Można - pisze z kolei Marcel mieć zaufanie tylko do jakiegoś «ty», do jakiejś rzeczywistości, która może spełniać funkcję «ty», być wzywana, stać się ucieczką" (G. Marcel, Tajemnica bytu, dz. cyt., s. 299). Zob. też J. Pieper, O miłości, nadziei i wierze, dz. cyt., s. 208-209.

59 K. Tarnowski, Usłyszeć niewidzialne..., dz. cyt., s. 318. 
w porządku, który ją nieskończenie przerasta, i zdając się na prowadzenie stojącej za nim siły, zakorzenia się w samej głębi rzeczywistości, będącej naraz źródłem, gwarantem i wyrazem tego, co ostateczne ${ }^{60}$.

Jest zatem zarówno postawą nasłuchiwania owego cichego głosu, który łagodnie, lecz stanowczo wzywa do odpowiedzi, jak i ufną afirmacją jego wiarygodności. Zanim jeszcze przez wiarę wyjdę poza siebie, dokonuje się we mnie tajemnicze scalenie przedmiotu i podmiotu ${ }^{61}$; niepodobna określić, skąd przychodzi ani dokąd zmierza to pytanie, a mimo to z mocą bezpośredniości staje mi ono naprzeciw, w zaproszeniu do wspólnej wędrówki wskazując sobie tylko znaną drogę. Tak oto przed wszelką wiedzą i nawet przed doświadczeniem - skoro nie okrzepło jeszcze w to, co dane - w niepowtarzalnym, a przeto nieporównywalnym i trudnym do opisania wydarzeniu, rodzi się postawa elementarnej gotowości i otwarcia się na przyjęcie czegoś spoza siebie ${ }^{62}$. Będąc odpowiedzią ${ }^{63}$, dowodzi, że

${ }^{60}$ Zob. K. Tarnowski, Ustyszeć niewidzialne..., dz. cyt., s. 316-320, gdzie autor przeprowadza analizę wiary emuna. Por. też K. Mech, Logos wiary..., dz. cyt., s. 17-29; K. Mech, Emuna i pistis, „Przegląd Religioznawczy” 247 (2013) nr 1, s. 22-28.

${ }^{61}$ „W przeciwieństwie do innych rodzajów doświadczenia nie ma jasnego wyraźnego oddzielenia przedmiotu i zrozumienia, rzeczywistości i odpowiedzi. Osoby religijne nie zawsze mają do czynienia z cichym i oddalonym obiektem, wobec którego zachowują uczuciową autonomię" (A. J. Heschel, Prorocy, przeł. A. Gorzkowski, Kraków 2014, s. 781). Podobnie pisze Frank na temat wiedzy „żywej”, innej od przedmiotowej, a leżącej u jej podstaw: „w wiedzy żywej [...] sama realność odsłania się w nas i dla nas, niejako mówi o sobie przez samą swą obecność" (S. L. Frank, Dowód ontologiczny..., dz. cyt., s. 139). Na temat zniesienia w doświadczeniu religijnym podziału na podmiot i przedmiot zob. np. T. Węcławski, Wspólny świat religii, Kraków 1995, s. 216, a także H. Perkowska, Bóg filozofów XX wieku. Wybrane koncepcje, Warszawa-Poznań 2001, s. 43; L. Dupré, Inny wymiar..., dz. cyt., s. 14.

62 „To, co spotyka mnie, coś mi mówi, ale co mówi, tego nie powie mi żadna tajemna wiedza, gdyż jeszcze nigdy dotąd nie zostało to powiedziane i nie składa się z głosek, które byłyby kiedykolwiek wyartykułowane. Jest to coś niewytłumaczalnego jak i nieprzekładalnego, coś, czego nie jestem w stanie wyjaśnić sobie ani zrozumieć; nie jest to nawet Coś, zostało to przecież włączone w moje życie, nie jest doświadczeniem, do którego można wrócić pamięcią niezależnie od kontekstu; pozostaje wciąż zagadnięciem owej chwili, od niej nieoddzielnym, pytaniem pytającego, które domaga się odpowiedzi” (M. Buber, Dialog, w: M. Buber, Ja i Ty. Wybór pism filozoficznych, przeł. J. Doktór, Warszawa 1992, s. 219).

63 „Całą historię ludzkości, tak jak rysuje ją Biblia, można streścić w jednym zdaniu: Bóg szuka człowieka. Wiara w Boga jest odpowiedzią na pytanie Boga” (A. J. Heschel, Bóg szukający człowieka..., dz. cyt., s. 173). „Religia zaczyna się od świadomości, że jesteśmy o coś pytani” (A. J. Heschel, 
nie istnieje fides ex nihilo; wiara to bowiem - bardziej udzielona niż samoistna - siła przyznania się do słabości, do nieusuwalnej zależności od czegoś większego i potężniejszego, co można jedynie spotkać i usłyszeć, a czego istnienie nie daje się dowieść, albowiem to ono, kiedy zechce, dowodzi samo siebie ${ }^{64}$. Dzięki temu spotkaniu i tej otwartości jest, by tak rzec, syntezą zarówno poznania, jak i doświadczenia, wzniesieniem każdego z nich na wyższy, inaczej nieosiągalny poziom; dopiero wierząc temu, który wie ${ }^{65}$, zwłaszcza jeśli wie absolutnie, możemy pokonać wiążące nas ograniczenia, przekroczyć potok pojedynczych i niepełnych danych, by wreszcie, patrząc cudzymi na razie oczami, uchwycić to, co nieuchwytne.

Warunkiem przeto poznania jest zarówno pokrewna intelektowi wiara pistis, jak i zawierzająca i oddana emuna; dopiero ona gwarantuje całkowitą, ponieważ poręczoną pełnym egzystencjalnym zaangażowaniem pewność ${ }^{66}$, i dopiero w niej prawdziwie dokonuje się próba, kiedy nie tylko treść sądu, na który przystaję, ale nade wszystko osoba, której uwierzyłem, wzywają mnie, by przezwyciężyć dojmującą niepewność i nie sprzeniewierzyć się udzielonej odpowiedzi. Dopiero owo niesprzeniewierzenie, czy raczej dokonywane mimo wszystko „bezustanne poświadczanie”67, stanowi o autentyczności wiary. Otwarcie się, odpowiedź jest w równej mierze obdarzeniem kredytem kogoś, co zaciągnięciem kredytu przez siebie samego, wzięciem na siebie odpowiedzialności za przyjętą w wierze

Bóg szukający człowieka..., dz. cyt., s. 207; A. J. Heschel, Człowiek nie jest sam..., dz. cyt., s. 62). „Wiara nie jest wytworem poszukiwania i próby, lecz odpowiedzią na wyzwanie, którego nikt nie może bezustannie ignorować" (A. J. Heschel, Człowiek nie jest sam..., dz. cyt., s. 69).

${ }^{64} \mathrm{Na}$ temat wnioskowania o istnieniu Boga zob. np. S. L. Frank, Niepojęte..., dz. cyt., s. 241-242.

65 Zob. J. Pieper, O miłości, nadziei i wierze, dz. cyt., s. 219, 222. O wierze jako udziale w Bożej mądrości i jako wyższym poziomie myślenia zob. A. J. Heschel, Bóg szukający człowieka..., dz. cyt., s. 150.

${ }_{66}$ Zob. L. Dupré, Inny wymiar..., dz. cyt., s. 49, 50: „Żadne obiektywne dane nie mogą nigdy zapewnić wymaganej przez wiarę absolutnej pewności. [...] Gdy chodzi o fakty historyczne, to mogą być one wystarczająco godne zaufania, aby usprawiedliwić wierzenie, ale nigdy nie uzasadniają absolutnej pewności wiary. W nieskończenie ważnej kwestii jedynie całkowite zaangażowanie może zrodzić absolutną pewność". Na temat ryzyka związanego z zawierzeniem zob. też uwagi K. Tarnowskiego, Ustyszeć niewidzialne..., dz. cyt., s. 165.

${ }^{67}$ „Nie ma wiary bez wierności. Wiara sama przez się nie jest odruchem duszy, uniesieniem, zachwytem. Wiara jest bezustannym poświadczeniem" (G. Marcel, Rozważania na temat wiary, dz. cyt., s. 310). 
prawdę. Inaczej niż w przekonaniu, powie Gabriel Marcel, w wierze nie zawłaszczam prawdy, lecz powierzam się jej wraz z całym swoim byciem: "Jeżeli wierzę w - czytamy - oznacza to, że siebie samego oddaję do dyspozycji albo też, że przyjmuję głębokie zobowiązanie, które dotyczy nie tylko tego, co mam, lecz także tego, czym jestem"68.

\section{Owoc wiary}

Choć wiara kroczy w ciemności, i choć, jak wskazaliśmy, bywa stopniowo wspomagana przez światło, sama jednak jest widoczna i sama w sobie winna być światłością. Skrywając się bez końca w dziedzinie głuchej wewnętrzności, nie dając się poznać nikomu poza samą sobą, może być najwyżej bezbożnym życzeniem próżnego umysłu. Jako modus bycia w ciele, wyraża się w działaniu; ponieważ jest aktem całego człowieka, a człowiek jest czymś więcej niż wnętrzem, sercem czy poznającym duchem, nieodłączny od wiary jest wydawany przez nią owoc. Może dlatego „wiara nie jest wiarą, jeśli nie towarzyszy jej i nie wypełnia jej nadzieja i miłość" 69 .

Źródło poznać podobna tylko po tym, co zeń wypływa; wiara jest warunkiem poznania poznawanym po skutkach, jakie przynosi, oddziałując w życiu wierzącego: w poznaniu bowiem prawda nie daje się oderwać od dobra. Wiara tylko wtedy jest godna wiary, gdy przynosi przemianę życia, a prawda wiary jest prawdą, która wyswobadza ${ }^{70}$. Jako „ziarno”71

68 G. Marcel, Tajemnica bytu, dz. cyt., s. 297.

69 B. Welte, Czym jest wiara?..., dz. cyt., s. 66. Por. P. Tillich, Dynamika wiary, dz. cyt., s. 119: „Wiara łączy się z miłością, miłość żyje w uczynkach - w tym sensie uczynki są symbolem urzeczywistnienia się wiary. [...] Z wiary pojętej jako stan ostatecznego zatroskania wynika potrzeba miłości i konieczność działania. Wiara jest też najgłębszym źródłem mocy miłości i działania”.

${ }^{70} \mathrm{U}$ Franka podobnie: kryterium oceny wiary religijnej stanowią jej moralne owoce; zob. T. Obolevitch, Problematyczny konkordyzm..., dz. cyt., s. 212. Zob. też B. Welte, Czas i tajemnica, dz. cyt., s. 337: „Prawda wiary polega [...] na tym, że czyni coś z człowiekiem, który dzięki wierze ją sobie przyswaja”. I dalej: „Dzięki przeobrażającej sile prawdy wiary, prawda staje się wolnością, a wolność miłością" (s. 338). Por. też M. Buber, Dialog, dz. cyt., s. 112: „Spotkanie z Bogiem przydarza się człowiekowi nie po to, by zajmował się Bogiem, lecz by okazał w świecie sens”.

${ }^{71}$ A. J. Heschel, Człowiek nie jest sam..., dz. cyt., s. 148. 
i „mennica”72 stanowi tylko pustą formę, jeśli nie wypełni się treścią dobrych czynów. Jak powie Heschel,

jeśli we wspomnieniu chwili religijnej intuicji możemy ujrzeć drogę, która scala nasze pocięte życiowe ścieżki, jednoczy to, co pozostawało w konflikcie - wiemy, iż jest to znak wskazujący nam drogę do Niego. Jeśli myśl rodzi pychę, dystans wobec cierpień innych ludzi i nieświadomość niebezpieczeństw, jakie niesie zło - wiemy, iż to zejście z Jego drogi. [...] Prawdziwe wejrzenie rozdziera zasłonę serca i obdarza człowieka mocą wzniesienia się ponad samego siebie ${ }^{73}$.

\section{Bibliografia}

Augustyn L., Myślenie z wnętrza objawienia. Studium filozofii Siemiona L. Franka, Kraków 2003.

Bierdiajew M., Rozważania o egzystencji. Filozofia samotności i wspólnoty, przeł. H. Paprocki, Kęty 2002.

Buber M., Dialog, w: M. Buber, Ja i Ty. Wybór pism filozoficznych, przeł. J. Doktór, Warszawa 1992, s. 207-247.

Dupré L., Inny wymiar. Filozofia religii, przekł. S. Lewandowska-Głuszyńska, Kraków 2003. Evdokimov P., Poznanie Boga w Kościele wschodnim, przeł. A. Liduchowska, Kraków 1996. Frank S., Dowód ontologiczny i inne pisma o wiedzy $i$ wierze, wybór, przekład i wstęp T. Obolevitch, Kraków 2007.

Frank S., Niepojęte. Ontologiczny wstęp do filozofii religii, tłum. T. Obolevitch, Tarnów 2007. Frank S., Pierwsze określenie i istota intuicji, przeł. B. Czardybon, „Logos i Ethos” 25 (2008) nr 2, s. 165-183.

Heschel A. J., Bóg szukający człowieka. Podstawy filozofi judaizmu, przekł. A. Gorzkowski, Kraków 2015.

Heschel A. J., Człowiek nie jest sam. Filozofia religii, tłum. K. Wojtkowska, Kraków 2008. Heschel A. J., Człowiek szukajacy Boga. Szkice o modlitwie i symbolach, tłum. V. Reder, Kraków 2008.

72 A. J. Heschel, Bóg szukający człowieka..., dz. cyt., s. 366.

73 A. J. Heschel, Bóg szukający człowieka..., dz. cyt., s. 205, 206. 
Heschel A. J., Kim jest człowiek?, przeł. K. Wojtkowska, Łódź 2014.

Heschel A. J., Prorocy, przekł. A. Gorzkowski, Kraków 2014.

Krasicki J., Człowiek i Bóg w tradycji rosyjskiej, Kraków 2012.

Marcel G., Od sprzeciwu do wezwania, przeł. S. Ławicki, Warszawa 1965.

Marcel G., Rozważania na temat wiary, w: G. Marcel, Być i mieć, przeł. D. Eska, Warszawa 2001, s. 292-312.

Marcel G., Tajemnica bytu, tłum. M. Frankiewicz, Kraków 1995.

Mech K., Logos wiary. Między boskościq a racjonalnością, Kraków 2008.

Obolevitch T., Problematyczny konkordyzm. Wiara $i$ wiedza w myśli Włodzimierza S. Sołowjowa i Siemiona L. Franka, Tarnów 2006.

Perkowska H., Bóg filozofów XX wieku. Wybrane koncepcje, Warszawa-Poznań 2001.

Pieper J., O miłości, nadziei i wierze, przeł. I. Gano, K. Michalski, Poznań 2000.

Rosyjska metafizyka religijna, red. T. Obolevitch, W. Kowalski, Tarnów 2009.

Szulakiewicz M., Religia i czas, Toruń 2008.

Tarnowski K., Ustyszeć niewidzialne. Zarys filozofii wiary, Kraków 2005.

Tillich P., Dynamika wiary, tłum. A. Szostkiewicz, Poznań 1987.

Unamuno M. de, O poczuciu tragiczności życia wśród ludzi i wśród narodów, przeł.

H. Woźniakowski, Kraków-Wrocław 1984.

Welte B., Czas i tajemnica, przeł. K. Święcicka, Warszawa 2000.

Welte B., Czym jest wiara? Rozważania o filozofii religii, przeł. W. Patyna, Warszawa 2000.

Welte B., Filozofia religii, tłum. G. Sowinski, Kraków 1996.

Węcławski T., Wiara ze stuchania i widzenie, „Znak” 473 (1994) nr 10, s. 76-81.

Węcławski T., Wspólny świat religii, Kraków 1995.

\section{Abstrakt}

Doświadczenie przed doświadczeniem:

wiara jako warunek poznania.

Wokół myśli Siemiona L. Franka i Abrahama J. Heschela

Koncepcje Siemiona L. Franka oraz Abrahama J. Heschela, chociaż różnią się od siebie, wykazują zarazem zasadniczą zbieżność tam, gdzie zbiegają się ze sobą rosyjska i żydowska filozofia religijna XIX i XX wieku. Celem tekstu jest zarówno wydobycie i wskazanie owych różnic i podobieństw, jak i, nade wszystko, podjęcie w ich 
towarzystwie namysłu nad zagadnieniem wiary. Ukazuje się ona jako kategoria tyleż swoista, co fundamentalna dla refleksji nad sytuacją człowieka w świecie. Będąc daleko więcej niż przyjęciem dogmatu, jawi się raczej fundującym doświadczenie aktem wglądu w niepojętą, lecz samooczywistą realność (Frank), otwarciem na niedostępną zmysłom ani rozumowi rzeczywistość tego, co niewysłowione (Heschel). Jako wewnętrzna siła egzystencji, która daje początek głębszemu i pełniejszemu poznaniu, łączy się zarazem z kategoriami właściwymi dla ludzkiego doświadczenia, takimi jak: rozum, tajemnica, ciemność i światło, słyszenie i widzenie, przeszłość i przyszłość, zawierzenie oraz ufność - które artykuł, uwzględniając szerszy kontekst myśli filozoficznej i religijnej, stara się uwypuklić i opisać.

\section{Słowa kluczowe}

wiara, poznanie, doświadczenie, Siemion L. Frank, Abraham J. Heschel, filozofia religii, filozofia człowieka, tajemnica, zaufanie, nadzieja, egzystencja

\section{Abstract \\ Experience Before Experience: Faith as a Condition of Knowledge. Around the Thoughts of Semyon L. Frank and Abraham J. Heschel}

The concepts of Siemion L. Frank and Abraham J. Heschel, despite differences, are convergent as far as Russian and Jewish religious philosophies of nineteenth and twentieth century converge with each other. The goal of the text is to both extract and indicate the differences and similarities, as well as, above all, to try to undertake in their company a reflection upon the question of faith. It turns out as a category both specific and fundamental for the human situation in the world. Being far more than adopting a dogma, it appears to be an insight into inconceivable, yet self-evident reality that establish the experience (Frank), an openness to the reality of the ineffable which is inaccessible to the senses or reason (Heschel). As an inner strength of existence which gives rise to a deeper and fuller cognition, it is connected at the same time with categories relevant to human experience, such as: reason, mystery, darkness and light, hearing and seeing, the past and the future, trust - all of which the article, considering the broader context of philosophical and religious thought, tries to emphasize and describe. 


\section{Keywords}

faith, knowledge, experience, Siemion L. Frank, Abraham J. Heschel, philosophy of religion, philosophy of a man, mystery, trust, hope, existence 